\title{
Evaluation of polymers for the liquid rhizobial formulation and their influence in the Rhizobium- Cowpea interaction
}

\author{
Diego Rivera ${ }^{1,2} \otimes$, Melissa Obando ${ }^{1,3}$, Helber Barbosa $^{2}$, Daniel Rojas Tapias ${ }^{1}$, \\ Ruth Bonilla Buitrago ${ }^{1}$
}

\begin{abstract}
To develop proposals in bacterial formulations applicable to the agricultural sector, a study of physicochemical and biological parameters of the polymeric materials is essential. Here, we evaluated the effects of eight polymers on the cellular viability of Rhizobium sp. G58 during a 2-month period. From these results, we selected the three polymers that yielded the best results in respect to the survival of the bacteria. An assay of the effect of the polymers on the symbiotic activity of Rhizobium-Cowpea and the agronomic parameters was conducted under greenhouse conditions, based on the principal component analysis. A positive effect was found in Rhizobium sp. G58 using the Tukey's Test $(\mathrm{p}<0.05)$ with sodium alginate $(0.5-1 \%)$ and hydroxypropyl methylcellulose-HPMC $(0.125-0.5 \%)$, while a significant decrease was established in cellular viability using polyethylene glycol-PEG, carbomer-Carbopol 940, and polyvinyl alcohol-PVA. The multivariate analysis indicated that the application of the polymers (sodium alginate and hydroxypropyl methylcellulose) in $0.5 \%$ concentration did not have negative effects on the symbiotic fixation of nitrogen or the process of nodulation. In conclusion, our results suggest the effectiveness of these polymers and the possibility of using them as carriers of bacterial formulation without affecting physiological processes.
\end{abstract}

Keywords: Rhizobium; polymers; formulation; analysis multivariate.

Edited by Alberto Acosta

1 Laboratorio de Microbiología de Suelos-Grupo Sistemas Agropecuarios Sostenibles, Centro de Biotecnología y Bioindustria-CBB; CP 11001000,

Corporación Colombiana de Investigación Agropecuaria-Corpoica Km 14 Vía Bogotá D.C., Colombia.

2 Universidad Nacional de Colombia-Facultad de Ciencias-Ciencias

Farmacéuticas.

3 Universidad Nacional de Colombia-Facultad de Agronomía-Fisiología vegetal.

Received: 05-03-2014 Accepted: 15-05-2014

Published on line: 02-07-2014

Citation: Rivera D, Obando M, Barbosa H, Rojas-Tapias D, Bonilla Buitrago R

(2014). Evaluation of polymers for the liquid rhizobial formulation and

their influence in the Rhizobium-Cowpea interaction. Universitas Scientiarum

19(3): 265-275 doi: 10.11144/Javeriana.SC19-3.eplr

Funding: Corporación Colombiana de Investigación Agropecuaria-Corpoica; Centro de Biotecnología y Bioindustria-CBB; Ministerio de Agricultura y Desarrollo Rural de Colombia-MADR; Departamento Administrativo de Ciencia Tecnología e Innovación-Colciencias and Dirección de Investigación-DIB.

Electronic supplementary material: N/A

\section{Introduction}

The Cowpea bean is a legume of economic and food security importance in tropical and subtropical underdeveloped countries (Araméndiz-Tatis et al. 2011, Cardona-Ayala et al.2013). Attempts to increase the yield of Cowpea beans in Caribbean regions have bolstered the pursuit of strategies to improve the development of the crop. A sustainable biotechnological alternative has integrated plant growth promoting rhizobacteriaPGPR, with new technologies of immobilization and efficient implementation of native rhizobia. In the roots of legumes, the symbiotic bacteria, commonly known as rhizobia, stimulate the formation of specialized structures or "nodules" in which nitrogen gas is reduced 
to ammonium (Sprent 2001, Angelini et al. 2011) . This symbiotic process contributes between $60-80 \%$ of the biological nitrogen fixation on the planet and provides a significant portion of the nitrogen in the soil that allows leguminous plants to grow without the use of nitrogenous fertilizers, protecting the agricultural potential of soils (Vance 1998).

Biofertilizers are available in various forms such as granules, which are applied to the soil after planting. However, large quantities of these biofertilizers are necessary for an efficient inoculation (Panter 2000, Lupwayi et al. 2006). Rhizobium-based biofertilizers, available in liquid form, are commonly used in South America mainly for soybeans, as liquid inoculants are more suitable for mechanical planting. On the other hand, worldwide, the use of peat as a bacterial carrier has decreased due to its fossil origin and that is extracted from a fragile natural environment. Alternative materials such as polymers are being widely studied to improve the quality and efficiency of rhizobial inoculants and to reduce production costs, as well as their impact on the environment (Albareda et al. 2008, Fernandes Júnior et al. 2012, Herrmann \& Lesueur 2013).

Polymers and individual compound formulations have been assessed as innovative carriers for rhizobia (Dommergues et al. 1979, Denardin \& Freire 2000, Deaker et al. 2007, Tittabutr et al. 2007), as well as related bacterial species (Bashan \& Gonzalez 1999). Therefore, new strategies to transport microorganism materials and methods for the immobilization of bacteria, when moving them to the field, are of high importance to maintain their physiological capabilities. The objectives of this investigation are to assess the effectiveness of different polymers on the rhizobial strain used in the formulation and to study the prototype formulations, under greenhouse conditions on the symbiotic activity of Rhizobium-legume as new carriers for rhizobia and their potential impact on the agricultural sector.

\section{Materials and methods}

Bacterial strain and growth conditions: Rhizobium sp. strain G58, with accession number JQ771467 was isolated from nodules of Cowpea [Vigna unguiculata (L.) Walp] in Guajira, Colombia, it was selected based on its potential as a plant growth promoting rhizobacteria-PGPR (Data unpublished). It was cryopreserved at $-20{ }^{\circ} \mathrm{C}$ in $30 \%$ glycerol at the Laboratorio de Microbiología de Suelos of Corpoica and reactivated in YM culture medium (Somasegaran \& Hoben 1994). For all experiments, the strain was cultivated in an Erlenmeyer flask with YM liquid medium through a process of batch fermentation for $24 \mathrm{~h}$ of shaking at $150 \mathrm{rpm}$ and $28 \pm 2{ }^{\circ} \mathrm{C}$.

Polymer characterization and compatibility with Rhizobium sp. G58: The following polymers were characterized by analyzing their viscosity grade, $\mathrm{pH}$, and were biotechnological applications with microorganisms and selected by cost and availability (Table 1). The eight polymeric materials used in this research comply with the specifications set by the USP pharmacopoeia. Two were sodium alginates of low and high molecular weight (FMC Biopolymer), hydroxypropyl methylcellulose-HPMC (Colorcon $\left.{ }^{\circledR}\right)$, two were polymers of polyethylene glycol-PEG of molecular weights of 4000 and 6000 respectively, polyvinyl alcohol-PVA, polyvinylpyrrolidone-PVP K15, and carbomer-carbopol 940 (Necardis SA). We standardized the culture conditions. When Rhirobiumsp. G58 grew in YM medium at an $\mathrm{OD}_{600}$ : 0.9 it was mixed with the polymers at three different concentrations using a sterilized disperser (Ultra turrax T25). These prototype formulations (polymers + Rhizobium sp. G58) were stored at room temperature in sterile polypropylene containers for subsequent evaluation for two months. All experiments were performed in triplicate. The effect of the formulated liquid on the bacterial viability were estimated by preparing serial dilutions in a buffer solution and plating $20 \mu \mathrm{l}$ of each dilution on a YM solid medium. Plates were incubated under aerobic conditions at $28 \pm 2{ }^{\circ} \mathrm{C}$ for 24-48 h. Data were expressed as log CFU ml ${ }^{-1}$. The polymers were studied with respect to their capacity rheology and importance as carriers of biological inoculants (Jung et al. 1982, Deaker et al. 2007, Trivedi \& Pandey 2008). Additionally, we measured (data no shown) the plant growth promoting activity [quantification of auxin (Glickmann \& Dessaux 1995) and phosphate solubilization (Pikovskaya 1948)] of the best prototypes.

Polymer film formation by using the casting technique: Of the eight polymers examined, the three 
Tabla 1. Characterization of polymers used for Rhizobium sp. G58 immobilization. *Viscosity was measured using a viscometer (Brookfield DV-III Ultra, Brookfield Engineering Laboratories, Inc., USA) equipped with a $\mathrm{N}^{\circ} 2$ needle at $25^{\circ} \mathrm{C}$ with $<100 \mathrm{rpm}$ agitation, depending on the polymer.

\begin{tabular}{|c|c|c|c|c|}
\hline Polymers & $\begin{array}{l}* \text { Viscosity } \\
\quad(\mathrm{cP})\end{array}$ & $\mathrm{pH}$ & Characteristics & $\begin{array}{l}\text { Applications with } \\
\text { microorganisms }\end{array}$ \\
\hline Polyethylene glycol 4000 (1) & 100 & $5.9 \pm 0.03$ & $\begin{array}{l}\text { Soluble in water, } \\
\text { suspension agents }\end{array}$ & Denardin \& Freire (2000) \\
\hline Polyethylene glycol 6000 (2) & 250 & $5.7 \pm 0.07$ & $\begin{array}{l}\text { Adhesive properties, } \\
\text { soluble in water }\end{array}$ & Temprano et al. (2002) \\
\hline Polyvinyl alcohol-PVA & 280 & $4.2 \pm 0.02$ & Stabilizing properties & $\begin{array}{l}\text { Deaker et al. (2007), } \\
\text { Kwon et al. (2009) }\end{array}$ \\
\hline Carbomer-Carbopol 940 & 12000 & $3.5 \pm 0.01$ & $\begin{array}{l}\text { Suspension agents and } \\
\text { adhesive }\end{array}$ & Kibbe (2000) \\
\hline Sodium alginate-low molecular weight (1) & $100-300$ & $6.9 \pm 0.25$ & Stabilizing, thickener & $\begin{array}{l}\text { Bashan et al. (2002), } \\
\text { Young et al. (2006) }\end{array}$ \\
\hline $\begin{array}{l}\text { Sodium alginate-high molecular } \\
\text { weight (2) }\end{array}$ & $600-900$ & $6.7 \pm 0.08$ & Agglutinant, stabilizing & $\begin{array}{l}\text { Yabur et al. (2007), } \\
\text { Bashan \& Gonzales (1999) }\end{array}$ \\
\hline Hydroxypropyl methyl cellulose-HPMC & 100 & $6.7 \pm 0.03$ & $\begin{array}{l}\text { Soluble in water, } \\
\text { controlled release }\end{array}$ & $\begin{array}{l}\text { Suvorova et al. (1999), } \\
\text { Fernandes Júnior et al. (2012) }\end{array}$ \\
\hline Polyvinylpyrrolidon-PVP K15 & $<100$ & $6.5 \pm 0.05$ & $\begin{array}{l}\text { Soluble in water, } \\
\text { bioadhesive }\end{array}$ & $\begin{array}{l}\text { Haffez et al. (1991), } \\
\text { Tittabutr et al. (2007) }\end{array}$ \\
\hline
\end{tabular}

with the most positive effect on cellular viability were selected (Table 2). The polymer films were obtained from the dispersion of polymers (sodium alginate and hydroxypropyl methylcellulose) in distilled water under environmentally controlled conditions and mechanical agitation at $400 \mathrm{rpm}$ using an RZR 2020 homogenizer (Heildoph). The polymers concentrations were $0.5 \%$. The polymer preparation was added to $15 \times 15 \mathrm{~cm}$ glass plates; in accordance with the casting method described by Bajdik et al. (2005) and was dried in an oven at $60 \pm 5^{\circ} \mathrm{C}$.
Determination of water vapor permeability: The water vapor permeability values were determined using the ASTM E96-95 method (1995). The films were placed onto glass plates and $30 \mathrm{~mL}$ of distilled water was added. Immediately, paraffin was added to the top border of the glass plates, which were subsequently closed. The glass plates, containing the films, were weighed and placed inside a desiccator. Permeability was determined every $12 \mathrm{~h}$ at room temperature and under controlled conditions of humidity. The changes in the weight of the plates were recorded over time.

Table 2. Characterization of additional properties of the better polymers selected. * Standard deviations for each value and variable are shown.

\begin{tabular}{lccc}
\hline \multicolumn{1}{c}{ Polymers } & Polymeric film Casting method $(\mathbf{m m})$ & Permeability-WVT $\left(\mathbf{g} / \mathbf{m}^{2} \mathbf{s}\right)$ & Swelling index-SI \\
\hline HPMC & $0.004 \pm 0.02$ & $0.0187 \pm 0.23$ & $1 \pm 0.08$ \\
Sodium alginate 1 & $0.002 \pm 0.01$ & $0.017 \pm 0.001$ & $0.2 \pm 0.04$ \\
Sodium alginate 2 & $0.003 \pm 0.02$ & $0.0198 \pm 0.15$ & $0.6 \pm 0.01$ \\
\hline
\end{tabular}


Swelling degree assay: The polymeric films, measuring $2 \times 2 \mathrm{~mm}$ in diameter, were placed on previously weighed steel meshes. The water absorbed by the film was calculated every 2 minutes. The degree of swelling was determined using the following equation ( $\mathrm{Li}$ et al. 1998): Swelling Index (SI) = Wt -Wo/Wo, where (Wt) is the weight of the film at time $t(t)$ and (Wo) is the weight of the film at time zero.

Greenhouse evaluation of the effect of the selected polymers on the symbiotic activity RhizobiumCowpea: The Cowpea bean is a native species of the indigenous of the Guajira-Colombia. The variety used was a black, warm-season legume called "black head" (Cruz de Carvalho et al. 1998). The seeds were sterilized by immersing them in 70\% ethanol for 30 seconds and rinsed three times with sterile distilled water. The seeds were subsequently placed in $2 \%$ sodium hypochlorite for one minute, and rinsed 10 times with sterile distilled water, then imbibed in sterile distilled water for $1 \mathrm{~h}$ following the protocol established by the Laboratorio de Microbiología de Suelos of Corpoica. After germinating, 4-5 day old incubated seeds were inhibited together with the 3 polymers previously selected according to their compatibility features, at a ratio $>500 \mu \mathrm{L}$ bacterial suspension $/ 60 \mathrm{~g}$ seed. Seedlings were sown in the pots in a sterile vermiculitesand ratio of $3: 1(\mathrm{w} / \mathrm{w})$. The plants were watered every two days using a hoagland nutrient solution described by Hoagland \& Arnon (1950). The formulated liquid prototypes of the best polymers (sodium alginate and hydroxypropyl methylcellulose-HPMC) were applied to a given polymer concentration of $0.5 \%$ and defined dose of inoculant/seed. Plants were allowed to grow for 60 days under greenhouse conditions at a temperature of $30 \pm 2{ }^{\circ} \mathrm{C}$ and $70 \%$ relative humidity. The nine variables evaluated were: root length, shoot length, nodule number, acetylene reduction assayARA, nodule biomass, root fresh weight, shoot fresh weight, root dry weight and shoot dry weight. Using XLSTAT 2012 software, we performed a principal components analysis-PCA on the variables evaluated.

Biological nitrogen fixation: Modulated roots, previously inoculated with the formulated liquid prototypes of Rbizobium sp. G58 were placed into a $280-\mathrm{ml}$ container, which was immediately sealed. A syringe was used to equalize the pressure in the container and the atmospheric pressure. Then, 10\% of the space in the container was replaced with acetylene, and the container was incubated for an hour at $30 \pm 2{ }^{\circ} \mathrm{C}$. The biological nitrogen fixation was estimated by using a Perkin Elmer gas chromatograph equipped with a flame ionization detector (FID) and a Poropak N 200/300 Mesh column measuring $6.0 \mathrm{ft}$ (in diameter) by $3.0 \mathrm{~mm}$ in accordance with the methods described by Hardy et al. (1968) and Meghvansi et al. (2010).

Experimental design and statistical analysis: We applied a completely randomized design and analysis of variance using the Tukey's test (HSD) with a confidence level of $95 \%(\alpha=0.05)$ using the SAS System for Windows 9.0. P-values of less than 0.05 were considered statistically significant.

\section{Results}

First, we biologically and physicochemically characterized the polymeric materials. The results obtained from the compatibility studies showed that polymers such as sodium alginate and HPMC supported a higher viability $(\mathrm{p}<0.05)$ in the Rhizobium sp. G58 compared to the control, in the three evaluated concentrations (Figure 1e and f).

The polymers that negatively affected cellular viability at the highest concentration were the following: PEG2 > PEG1 > PVA > Carbomer (Figure $1 \mathrm{a}$ and $\mathrm{b}$ ). The rhizobial strain, which was treated with polyethylene glycol (PEG) polymers of different molecular weights, showed a loss of viability during the 2-month evaluation at all concentrations assayed $(p>0.05)$. The control showed a better response, compared to the polyethylene glycol treatments (Figure 1a and b).

Based on the results of the compatibility studies, we selected the sodium alginate and hydroxypropyl methylcellulose polymers. Then, we evaluated additional physical properties, namely, swelling, permeability, and film formation, to allow the effective analysis of the polymers when they were applied directly to the plants (Table 2). This evaluation is vital; it allows us to analyze the release of active compounds in the polymeric matrix and to correlate the release efficiency with bacterial deposition in soil conditions. 

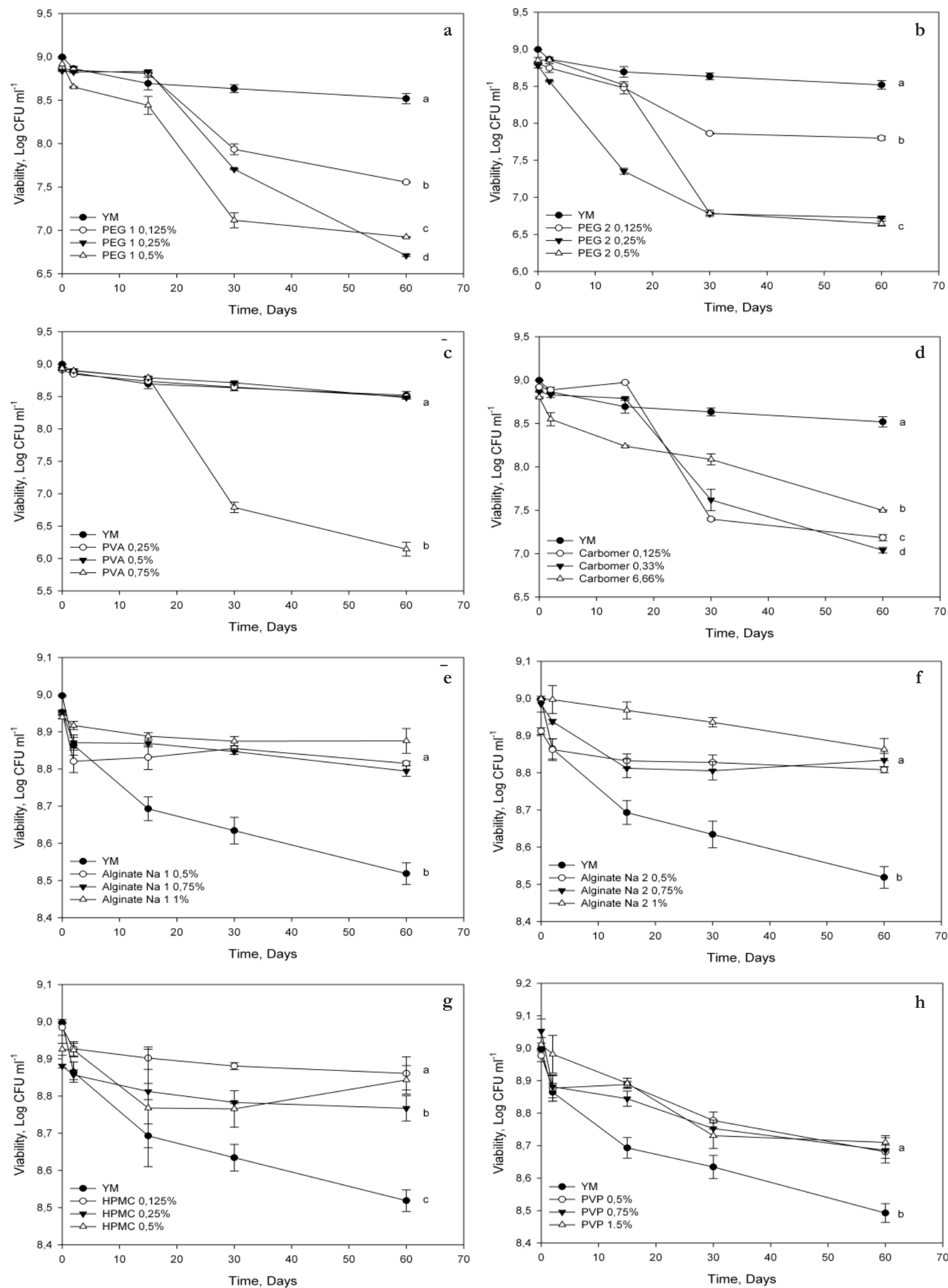

Fig. 1. Effect of eight polymers on the viability of Rhizobium sp. G58 during a 2-month evaluation. a. PEG 1 (MW: 4000), b. PEG 2 (MW: 6000), c. PVA, d. Carbomer 940, e. Sodium alginate 1 (Low molecular weight), f. Sodium alginate 2 (high molecular weight), g. HPMC, h. PVP under three concentrations). Each value represents the mean of three replicates. Different letter shows statistically significant differences by Tukey's HSD test $(p<0.05)$. Error bars represent standard deviation. 
The results obtained in the film formation test demonstrated the polymeric film formation using a casting method (Table 2). These polymers had presented these characteristics, previously, in the concentrations selected. These characteristics enable the retention of the active ingredient (microorganism) in its matrix for a gradual release. In the permeability assay, the results demonstrated that the polymers exhibited water vapor permeability (Table 2). However, the sodium alginate films showed the highest permeation capacity, followed by the HPMC films.

We also analyzed the maximum water content that the polymeric materials could retain before disintegration. The data demonstrated uniformity in the swelling process during the evaluation period. In terms of film swelling speed (retained water without the loss of its initial shape), after 4 minutes, the weight-gain curve decreased significantly, and the films reached their water retention limit and were saturated. However, observation of this limit was impossible for most of the films as most of them lost their integrity during the evaluation, probably because of insufficient thickness.

The effect of polymers on the biological activity of the bacteria in the Cowpeas was analyzed by using principal component multivariate analysis (Figure $2 \mathrm{a}, \mathbf{b}, \mathbf{c}$ ). Of this variation, $48.28 \%$ could be explained by the first principal component (PC1), $26.21 \%$ by the second principal component (PC2), and $15.46 \%$ by the third principal component (PC3) (Table 3). The information contained in the nine original response variables could be reduced to three that provided most of the experimental information. The factor loading analysis obtained from the principal component analysis (PCA) demonstrated the influence of each variable on the principal components. This analysis revealed the association of PC1 with the establishment of the symbiosis between the Rhirobium sp. G58 strain and the Cowpea plant. PC2 was associated primarily with the plant size, and PC3 was associated with the nutrient translocation in the plant. Pearson's correlation coefficient for highly weighted variables with high factor loading under principal component (Table 3).
Table 3. Results of the principal-components analysis (PCA) of the variables in plant and aggrupation the components by multivariate statistics. $\mathrm{PC}=$ principal component. In bold letter factor loadings are considered highly weighted when within $10 \%$ of variation of the absolute values of the highest factor loading in each PC.

\begin{tabular}{lrrr}
\hline Component & & & \\
\hline Statistics & PC1 & \multicolumn{1}{c}{ PC2 } & \multicolumn{1}{c}{ PC3 } \\
Eigenvalor & 4,346 & 2,359 & 1,392 \\
\% variance & 48,289 & 26,217 & 15,464 \\
\% cumulative & 48,289 & 74,506 & 89,97 \\
Factor Loading & & & \\
Variables & & & \\
Root length & $\mathbf{0 , 9 3 8}$ & $-0,116$ & $-0,122$ \\
Shoot length & $\mathbf{0 , 5 3}$ & $\mathbf{0 , 6 1 5}$ & $\mathbf{0 , 4 1 9}$ \\
Nodule number & $\mathbf{0 , 9 5 5}$ & $-0,137$ & $-0,012$ \\
ARA & $\mathbf{0 , 9 8 1}$ & $-0,066$ & $-0,041$ \\
Nodule biomass & $\mathbf{0 , 9 9}$ & $-0,038$ & 0,052 \\
Root fresh weight & 0,094 & $\mathbf{0 , 9 3 5}$ & $-0,246$ \\
Shoot fresh weight & 0,175 & $-0,094$ & $\mathbf{0 , 9 5 9}$ \\
Root dry weight & 0,155 & $\mathbf{0 , 9 5 2}$ & $-0,135$ \\
Shoot dry weight & $-0,518$ & 0,391 & $\mathbf{0 , 4 4 6}$ \\
\hline
\end{tabular}

The contribution of each component in the multivariate model of the principal components is described in Figure 2. The use of alginate and HPMC treatments produced an increase in the symbiosis between the bacteria and the plant, illustrated by the PC1 on the positive side of the axis. Regarding PC2, treatments that fall towards the negative side of the axis show a decrease in plant size. For PC3, treatments positioned towards the positive side of the axis imply that there is a higher nutrient translocation from the roots to the shoot length of the plant (Figure 2).

The sodium alginate 1 (followed by HPMC and sodium alginate 2 , in this order) was effective at stimulating nitrogen biological fixation and transporting assimilates to the rest of the plant; this is associated with an increase in the dry biomass and an increase in the shoot length of the plant (Figure 2).

Based on the results obtained in the PCA, we inferred that the most effective treatment to establish 

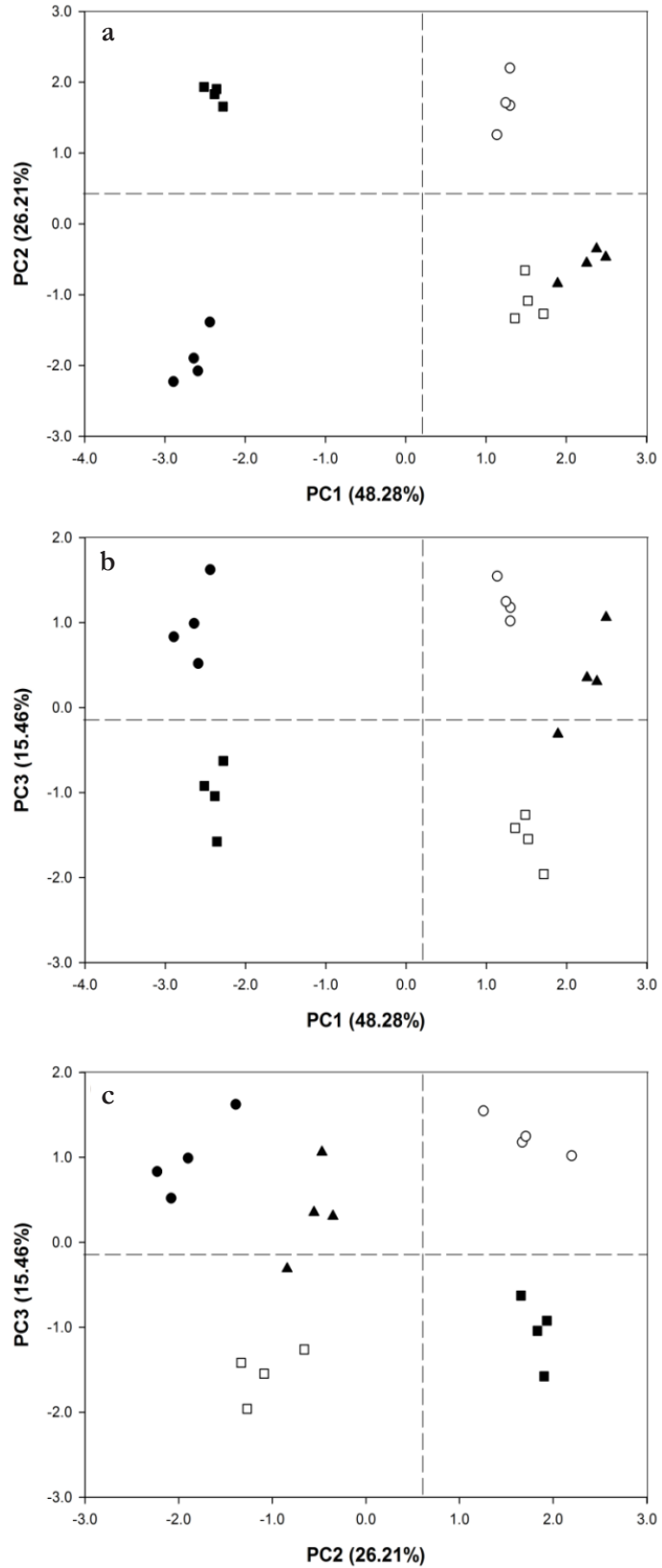

Fig. 2. Principal component analysis of the polymer treatments on the legume. a. Dispersion diagram of the greenhouse experiment with components PC1 (associated with the establishment of the symbiosis between the Rhizobium sp. G58 and the Cowpea plant) and PC2 (associated primarily with the plant size); $\mathbf{b}$. Dispersion diagram of the greenhouse experiment with components PC1 and PC3 (associated with the nutrient translocation in the plant), and c. Dispersion diagram of the greenhouse experiment with components PC2 and PC3. Absolute control (匹), YM medium (•), $\mathrm{YM}+$ sodium alginate 1 (O), $\mathrm{YM}+$ sodium alginate 2 (ם), YM + HPMC $(\boldsymbol{\Delta})$. Each point represents the mean value of four determinations. the symbiosis without affecting plant growth is YM with sodium alginate 1 (Figure 2); this also favors nutrient translocation. The results from the YM with sodium alginate 1 treatment fell in quadrant I of the plane, which, according to the factorial loading analysis, show higher biological activity. The two treatments with YM sodium alginate produced good nodulation, but a negative effect on plant growth, possibly related to the viscosity. As a result, we can infer that the polymer interferes with the uptake of some essential minerals necessary for physiological processes; therefore, the polymer interferes with nutrient translocation; this partially confirms our hypothesis (Figure 2).

\section{Discussion}

The compatibility studies yielded results about the polymers that disagree with the ones reported by Tittabutr et al. (2007) in which the use of polymers at percentages $<0.5 \%$ led to a reduction in the cell viability of rhizobia strains. In contrast, Bashan et al. (2002) demonstrated benefits of alginates to immobilize plant growth promoting bacteria (PGPB) and its benefits to agriculture, highlighting it as one the most compatible polymers with this bacteria, with the ability to protect them against adverse environmental conditions (Yabur et al. 2007). The alginates used in our study (sodium alginate 1 and 2) markedly differ in terms of the block conformation of their chemical structures (Zimmermann et al. 2007) (Figure 1e and f); however, this effect depended on the type of bacterial species assessed. Therefore, prior to polymer utilization, it is important to perform a physicochemical characterization to obtain information that contributes to the correct use of these materials and their compatibility with PGPR.

Because of its rheological properties, one of the polymers used was HPMC; this polymer is a semisynthetic cellulose-derived polymer containing methyl and hydroxypropyl groups and is used for the controlled release of different active principles (Kiil \& Dam-Johansen 2003). This polymer is an efficient bacterial carrier for longer periods and acts as a stabilizing agent in suspension (Ansel et al. 2004). Therefore, results were favorable for this polymer 
in Rbizobium sp. G58. These results are similar to the reports by Fernandes Júnior et al. (2012), in which they employed a cellulose named carboxymethylcelluloseCMC to seeds that were previously inoculated with rhizobia.

The use of polyethylene glycol yielded similar results to those obtained by Denardin \& Freire (2000), who observed a reduction in the posterior viability of Bradyrbizobium elkanii strains using PEG polymers, in contrast to results by Tittabutr et al. (2007). Zahran \& Sprent (1986) stated that PEG interfered with the process of infection in the root hairs of the bean plant Vicia faba $L$ and inhibited plant nodules numbers by $50 \%$.

The ability to form a polymeric film was assessed using the physicochemical properties of the polymers; the results obtained demonstrated that the evaluated polymers (sodium alginate and HPMC) have this characteristic. This method demonstrates the ability of the polymer to integrate different active compounds of pharmaceutical interest into its matrix and the biotechnological applications of their controlled release (Perioli et al. 2004, Trivedy \& Pandey 2008). The polymers used at these concentrations exhibited these integrative and release properties, which may protect the microorganism and gradually release it under certain conditions. Moreover, this characteristic was supported by the evaluation of the swelling capacity and the disintegration of the polymer in a buffer solution with a $\mathrm{pH}$ similar to the soil where this microorganism was isolated.

Additionally, the permeability assay revealed the efficiency of the polymers to transport water vapor through their structures (Perioli et al. 2004). The values obtained are similar to those reported for polymeric membrane permeability (Fulzele et al. 2002, Akgharia et al. 2006, Villalobos et al. 2006, Aungsupravate et al. 2008). This information may be useful for future formulations of the controlled release of active compounds (Perioli et al. 2004), in this case, it would permit a gradual release of the microorganism, dependent on its level of permeability.

Finally, the swelling capacity of a polymeric film depends on the balance between the net hydrophilic groups, which stabilize the low-molecular-weight liquids in the pores of the structure, and the electrostatic force that counter increases in volume. HPMC showed the highest water retaining ability, possibly because it contains more hydrophilic substituents (Perioli et al. 2004), followed by the alginates because of their capacity to form a weak gel with a lower degree of crosslinking and a lower water-retaining capacity (Lieberman \& Lachman 1982).

The evaluations of the interaction of the sodium alginate polymers and HPMC with Rhizobium sp. G58 presented a good symbiosis in the plant (Figure 2) for which these polymers had no biological incidence, and they did not influence any structural property in this process. Thus, the symbiosis was not interrupted despite the presence of these materials. The previous may be attributed to accelerated metabolic activities involved in the nodulation process, which requires the expression of specific nodulation genes (nod), leading to the synthesis of signaling molecules that induce nodule morphogenesis and the nutrient accumulation necessary for those processes (Zimmermann et al. 2007).

The principal component, PC3, showed nutrient transport without effects on the evaluated polymers (Figure 2). For this reason, when the rhizobia fix the nitrogen in the atmosphere in the root through the nodules, which transfer assimilates to the whole plant affecting plant growth and accumulates nutrients that are subsequently transported to the rest of the plant (Hirsch et al. 2001). The results obtained for sodium alginate 1 , may have been superior due to the concentration and type of polymer. These properties were attributed to the structure of the alginate polymer and its low viscosity (Zimmermann et al. 2007). In contrast, the more rigid structure and the high viscosity of the sodium alginate 2 polymers may have influenced the response (Zimmermann et al. 2007). Rawsthorne \& Summerfield (1984) obtained similar results in studies that showed an increased nitrogen fixation and higher nodule dry weights using alginate gel compared to controls.

\section{Conclusion}

Currently, the application of polymers in bacterial formulation is considered to be of high importance as an innovative technological strategy to maintain the metabolic stability of microorganisms. The data demonstrate that sodium alginate and HPMC 
were the most effective in improving the viability of the Rhizobium sp. G58 without affecting the bacterial physiology. The results showed that under greenhouse conditions, optimal symbiosis was established between the bacteria and the Cowpea plant [Vigna unguiculata (L.) Walp], contributing effectively to nodulation without affecting other physiological processes. Based on this, new challenges may arise to evaluate the compatibility of the sodium alginate and HPMC, as well as new methods of the controlled release of these polymeric materials with other rhizobial strains and legume crops in Colombia.

\section{Acknowledgments}

The authors express their gratitude to Corporación Colombiana de Investigación Agropecuaria-Corpoica, Centro de Biotecnología y Bioindustria-CBB, Ministerio de Agricultura y Desarrollo Rural de Colombia-MADR, Project codeMADR N 2008H1560, Departamento Administrativo de Ciencia Tecnología e Innovación-Colciencias and Dirección de Investigación-DIB-Universidad Nacional de Colombia, Bogota for the support and collaboration in the execution of research.

\section{Conflicts of interest}

The authors declare that they have no conflicts of interest to disclose.

\section{References}

Akhgaria A, Farahmanda F, Afrasiabi H, Garekania F, Sadeghia T, Vandammeb T (2006) "Permeability and swelling studies on free films containing inulin in combination with different polymethacrylates aimed for colonic drug delivery" European Journal of Pharmacentical Sciences 2: 307-314

Albareda M, Rodríguez-Navarro DN, Camacho M, Temprano FJ (2008) Alternatives to peat as a carrier for rhizobia inoculants: solid and liquid formulations. Soil Biology and Biochemistry 40: 2771-2779

Angelini J, Ibáñez F, Taurian T, Tonelli ML, Valetti L, Fabra A (2011) A Study on the Prevalence of Bacteria that Occupy Nodules within Single Peanut Plants. Curr Microbiol 62:1752-1759

Ansel HC, Allen LV, Popovich NG (2004) Ansel's Pharmaceutical Dosage Forms and Drug Delivery Systems. $8^{\text {a }}$ Edición. Lea \& Febiger, Philadelphia
Araméndiz-Tatis H, Espitia-Camacho M, Sierra CM (2011) Comportamiento agronómico de líneas promisorias de frijol caupí Vigna unguiculata L. Walp en el Valle del Sinú. Temas agrarios 16:(2): 9-17

ASTM (1995) Standard test methods for water vapor transmission of materials. ASTM E96-95. In ASTM book of standards, pp. 697-704. Philadelphia: ASTM

Aungsupravate O, Lucas D, Abu Hassan N, Tonge M, Warrender G, Castignolles P, Gaborieau M, Gilbert R (2008) "Water vapour transmission in butadieneMMA-methacrylic acid latex films" European Polymer Journal 44: 342-356

Bajdik J, Regdon G, Marek T, Eros I, Suvegh K (2005) “The effect of the solvent on the film forming parameters of hydroxypropyl-cellulose", Internacional Journal of Pharmaceutics 301-192

Bashan Y, Gonzales LE (1999) Long-term survival of the plant-growth-promoting bacteria Azospirillum brasilense and Pseudomonas fluorescens in dry alginate inoculant. Applied Microbiology and Biotechnology 51: 262-266

Bashan Y, Hernandez JP, Levya LA, Bacilio M (2002) Alginate microbeads as inoculant carriers for plant growth-promoting bacteria. Biol Fertil Soils 35: 359-368

Cruz de Carvalho MH, Laffray D, Louguet P (1998) Comparison of the physiological responses of Phaseolus vulgaris and Vigna unguiculata cultivars when submitted to drought conditions. Environmental and Experimental Botany 40: 197-207

Cardona-Ayala C, Jarma-Orozco A, Araméndiz-Tatis H (2013) Mecanismos de adaptación a sequía en caupí (Vigna unguiculata (L.) Walp.). Una revisión. Revista Colombiana de Ciencias Hortícolas 7(2): 277-288

Deaker R, Roughley RJ, Kennedy IR (2007) Desiccation tolerance of rhizobia when protected by synthetic polymers. Soil Biology and Biochemistry 39: 573-580

Denardin ND, Freire JRJ (2000) Assessment of polymers for the formulation of legume inoculants. World Journal of Microbiology and Biotechnology 16: 215-217

Dommergues YR, Diem HG, Divies C (1979) Polyacrylamide-entrapped Rhizobium as an inoculant for legumes. Applied and Environmental Microbiology 37: 779-781

Fernandes Júnior PI, Da Silva Júnior EB, Da Silva Júnior S, Da Silva e Santos CE, Oliveira PJ, Rumjanek NG, Vieira Martins LM, Xavier GR (2012) Performance of polymer compositions as carrier to Cowpea rhizobial inoculant formulations: Survival of rhizobia in preinoculated seeds and field efficiency. African Journal of Biotechnology 11(12): 2945-2951

Fulzele S, Satturwar P, Dorle A (2002) "Polymerized rosin: novel film forming polymer for drug delivery" International Journal of Pharmaceutics 249: 175-184 
Glickmann E, Dessaux Y (1995) A critical examination of the specificity of the salkowski reagent for indolic compounds produced by phytopathogenic bacteria. Applied and Environmental Microbiology 61: 793-796

Haffez FY, Asad S, Malik KA (1991) The effect of high temperature on Vigna radiata nodulation and growth with different bradyrbizobial strains. Environ Exp Bot 31: 285-294

Hardy RWF, Holsten RD, Jackson EK, Burns RC (1968) Acetylene ethylene assay for $\mathrm{N}_{2}$ fixation: laboratory and field evaluation. Plant Physiology 43: 1185-1207

Herrmann L, Lesueur D (2013) Challenges of formulation and quality of biofertilizers for successful inoculation. Appl Microbiol Biotechnol 97: 8859-8873

Hirsch AM, Lum MR, Downie JA (2001) What Makes the Rhizobia-Legume Symbiosis So Special?. Plant Physiology 127: 1484-1492

Hoagland DR, Arnon DI (1950) A water culture method for growing plants without soil. California Agricultural Experimental Station Circular 347

Jung G, Mugnier J, Diem HG, Dommergues YR (1982) Polymer-entrapped Rhizobium as an inoculant for legumes. Plant and Soil 65: 219-231

Kibbe A (2000) Handbook of pharmaceuticals excipients. Third edition. Washington DC. London, United Kingdom: American Pharmaceutical Association (APha)

Kiil S, Dam-Johansen K (2003) Controlled drug delivery from swellable hydroxypropylmethylcellulose matrices: model-based analysis of observed radial front movements. Journal of Controlled Release 90: 1-21

Kwon KH, Jung KY, Yeom SH (2009) Comparison between entrapment methods for phenol removal and operation of bioreactor packed with co-entrapped activated carbon and Pseudomonas fluorescence KNU417. Bioprocess Biosyst Eng 32: 249-256

Li JK, Wang N and Wu X (1998) "Poly(vinyl alcohol) nanoparticles prepared by freezing-thawing process for protein/peptide drug delivery". Journal of Controlled Release 56: 117-126

Lieberman H, Lachman L (1982) Pharmaceutical Dosage Forms-Tablets, Marcel Dekker, New York, Vol 3, pp. 138-148

Lupwayi NZ, Clayton GW, Rice WA (2006) Rhizobial inoculants for legume crops. Journal of Crop Improvement 15: 289-321

Meghvansi MK, Prasad K, Mahna SK (2010) Symbiotic potential, competitiveness and compatibility of indigenous Bradyrbizobium japonicum isolates to three soybean genotypes of two distinct agro-climatic regions of Rajasthan, India. Saudi Journal of Biological Sciences 17: 303-310
Panter S, Thomson R, de Bruxelles G, Laver D, Trevaskis B, Udvardi M (2000) Identification with proteomics of novel proteins associated with the peribacteroid membrane of soybean root nodules. Mol Plant Microbe Interact 13: 325-333

Perioli L, Ambrogi V, Angelini F, Ricci M, Giovagnoli S, Capucella M, Rossi C (2004) Development of mucoadhesive patches for buccal administration of ibuprofen. Journal of Controlled Release 99

Pikovskaya R (1948) Mobilization of phosphorus in soil in connection with the vital activity in some microbial species. Mikrobiologiya. 17: 362-370

Rawsthorne S, Summerfield RJ (1984) An assessment of different techniques for inoculating Phaseolus vulgaris with Rbizobium Expl Agric 20: 119-127

Somasegaran P, Hoben HJ (1994) Handbook for rhizobia. Springer Verlag. New York. p. 50

Sprent JI (2001) Nodulation in legumes. Royal Botanic Gardens, Kew, UK

Suvorova AI, Tjukova IS, Trufanova EI (1999) Thermodynamic and diffusion properties of biodegradable systems based on starch and cellulose derivatives. Journal of Polymers and the Environment 7: 35-40

Temprano FJ, Albareda M, Camacho M, Daza A, Santamaría C, Rodríguez-navarro DN (2002) Survival of several Rbizobium/Bradyrhizobium strains on different inoculant formulations and inoculated seeds. International Microbiology 5: 81-86

Tittabutr P, Payakaponga W, Teaumroonga N, Singletonb W, Boonkerda N (2007) Growth, Survival and Field Performance of Bradyrhizobial Liquid Inoculant Formulations with Polymeric Additives. Science Asia 33: 69-77

Trivedi P, Pandey A (2008) Plant growth promotion abilities and formulation of Bacillus megaterium strain B 388 (MTCC6521) isolated from a temperate Himalayan location. Indian Journal of Microbiology 48: 342-347

Vance CP (1998) Legume symbiotic nitrogen fixation: agronomic aspects. In: Spaink HP, Kondorosi A, Hooykaas PJJ, eds. The Rhizobiaceae. Dordrecht: Kluwer Academic Publishers. 509-530

Villalobos R, Hernández P, Muñoz A (2006) “Effect of surfactants on water sorption and barrier properties of hydroxypropyl methylcellulose films", Food Hydrocolloids 20: 502-509

Yabur R, Bashan Y, Hernández-Carmona G (2007) Alginate from the macroalgae Sargassum sinicola as a novel source for microbial immobilization material in wastewater treatment and plant growth promotion. J. Appl. Phycol 19: $43-53$ 
Young CC, Rekha PD, Lai WA, Arun AB (2006) Encapsulation of Plant Growth-Promoting Bacteria in Alginate Beads Enriched With Humic Acid. Biotechnology and Bioengineering 95, No. 1. doi: 10.1002/bit.20957

Zahran HH, Sprent JI (1986) Effects of sodium chloride and polyethyleneglycol on root-hair infection and nodulation of Vicia faba L. plants by Rhizobium leguminosarum. Planta 167: 303-309
Evaluación de polímeros para la formulación líquida de rizobios e influencia en la interacción Rhizobium-caupí

Resumen. Para el desarrollo de propuestas en formulaciones bacterianas aplicadas al sector agropecuario, se hace necesario el estudio de parámetros fisicoquímicos y biológicos de materiales poliméricos. En este estudio, evaluamos el efecto de ocho polímeros sobre la viabilidad celular de Rbirobium sp. G58 durante 2 meses. Obtenidos estos resultados, se seleccionaron los 3 polímeros que tuvieron la mejor respuesta en la supervivencia de la bacteria. Se realizó un ensayo bajo invernadero del efecto de los polímeros sobre la actividad simbiótica de RhizobiumCowpea y de los parámetros agronómicos, el cual fue realizado por un análisis multivariado de componentes principales. Se estableció un efecto positivo mediante el test de Tuckey's $(\mathrm{p}<0.05)$ en Rhizobium sp. G58 utilizando alginato de sodio $(0.5-1 \%)$ e hidroxipropilmetilcelulosa-HPMC (0.125-0.5\%). Mientras que, se obtuvo un descenso significativo en la viabilidad celular con polietilenglicol-PEG, carbomero-Carbopol 940, y alcohol polivinílico-PVA. El análisis multivariado indicó que la aplicación de los polímeros (alginato de sodio e hidroxipropilmetilcelulosa) a una concentración de $0.5 \%$, no afectaron negativamente la actividad de fijación simbiótica de nitrógeno, ni el proceso de nodulación. En conclusión, nuestros resultados sugieren la efectividad de estos polímeros con Rhizobium sp. y podrían ser empleados como soportes para formulaciones bacterianas sin afectar procesos fisiológicos.

Palabras clave: Rbizobium; polímeros; formulación; análisis multivariado.
Zimmermann H, Wählisch F, Baier C, Westhoff M, Reuss R, Zimmermann D, Behringer M, Ehrhart F, KatsenGloba A, Giese C, Marx U, Sukhorukov VL, Vásquez JA, Jakob P, Shirley SG, Zimmermann U (2007) Physical and biological properties of barium crosslinked alginate membranes. Biomaterials 28 (7):1327-45
Avaliaçáo de polímeros para a formulaçáo líquida de rizobios e influência na interaçáo Rhizobium-caupí

Resumo. Para o desenvolvimento de propostas em formulações bacterianas aplicadas ao setor agropecuário, faz-se necessário o estudo de parâmetros fisicoquímicos e biológicos de materiais poliméricos. Neste estudo, avaliamos o efeito de oito polímeros sobre a viabilidade celular de Rhizobium sp. G58 durante 2 meses. Selecionaram-se os 3 polímeros que tiveram a melhor resposta na sobrevivência da bactéria. Estabeleceuse um efeito positivo mediante o teste de Tuckey's $(\mathrm{p}<0.05)$ em Rbizobium sp. G58 usando alginato de sodio (0.5-1\%) e hidroxipropilmetilcelulosa-HPMC (0.125-0.5\%). Enquanto, obteve-se um descenso significativo na viabilidade celular com polietilenglicol-PEG, carbómero-Carbopol 940, e álcool polivinílico-PVA. A análise multivariado indicou que a aplicação dos polímeros (alginato de sodio e hidroxipropilmetilcelulose) a uma concentração de $0.5 \%$, não afetaram negativamente a atividade de fixação simbiótica de nitrogênio, nem o processo de nodulación. Em conclusão, os resultados sugerem a efetividade destes polímeros com Rbizobium sp. e poderiam ser empregues como suporte para formulações bacterianas sem afetar processos fisiológicos.

Palavras-chave: Rhiz̧obium; polímeros; formulação; análise multivariado. 